\title{
Impact of Livestock Grazing on Abundance and Community Structure of Macro- invertebrate fauna of Ovia River, Edo State, Nigeria
}

\section{${ }^{* 1}{ }^{1}$ GGANMWONYI IGIOGBE $^{1 *}$, IRIABGONSE FASIPE $^{2}$ EMERIBE, $^{*}$ CHUKWUDI $^{1}$}

\author{
${ }^{1}$ National Centre for Energy and Environment, Benin City \\ ${ }^{2}$ Department of Animal and Environmental Biology, University of Benin, Benin City, Nigeria
}

\begin{abstract}
A survey of the impact of cattle grazing on macro invertebrate fauna of Ovia River was carried out between January and June 2004. Macro invertebrate and water samples were collected from three sampling locations; station I (new grazing area for cattle), station II (initial grazing area) and station III (control location). A total of 33 taxa of macro invertebrates with 831 individuals were encountered in the study. The overall abundance of macro invertebrates was highly significantly different $(\mathrm{p}<0.01)$ among the study stations. A posteriori Dunnett's T3 test showed that the abundance was significantly higher in stations I and III. The low species abundance in station II is an indication of the grazing effect of the herds of cattle, which resulted in the loss of riparian vegetation and eventually the continuous sedimentation of the station during rainfall events. In view of this, governments at all levels should make efforts to establish dedicated pasture lands for livestock grazing across the country. ( ) JASEM
\end{abstract}

http://dx.doi.org/10.4314/jasem.v19i4.27

\section{Introduction}

Land-use practices, such as widespread deforestation and alteration of natural vegetation for forestry, agriculture, livestock grazing and urban land-use, has potential to influence the condition of our freshwater ecosystems and biota (Collier and Quinn 2003; Thompson and Townsend 2003; Allan 2004; Jones et al. 2011; Virbickas et al., 2011). These practices generally result in significant loss or change of terrestrial and riparian vegetation, increased fine sediment loads, increased nutrient and chemical inputs, altered temperature and hydrological regimes and loss of large woody debris into nearby streams (Thompson and Townsend 2003; Allan 2004; Extence et al., 2013). In addition, land-use change significantly impact on stream macroinvertebrate communities, often causing a shift towards more pollution tolerant taxa such as Diptera (Chironomidae), Mollusca and Oligochaeta dominating the system and a decline in pollution sensitive taxa such as Ephemeroptera, Plecoptera and Trichoptera (Harding et al. 2000; Kenney et al., 2009). Collectively, these land-use effects constitute an ecological disturbance and it can continue to affect stream macroinvertebrate community structure and function if left unmanaged (Lake 2000; Collier and Quinn 2003).

Since the $20^{\text {th }}$ century, Nigeria has witnessed land-use change and urbanization. This has given rise to land fragmentation including the absence of dedicated pasture lands, a situation that has resulted in the movement of cattle herders from place to place in search of pasture land and water for their cattle. In Edo State, pasture lands close to rivers and streams are usually over grazed. This usually leads to the loss of riparian vegetation, sedimentation of the river or stream and in some cases low abundance of invertebrate fauna (Masifwa et al., 2001).

Many limnological studies in Nigeria have highlighted the abundance of macroinvertebrates, their community structure, relationship between the water quality of a river and the macro invertebrates, the ecological role of macroinvertebrates in freshwater ecosystem and the impact of pollution on their abundance and diversity (Wallace and Webster, 1999; Imoobe and Ohiozebau, 2010; Ajuzie, 2012; Adeogun and Fafioye, 2011; Nkwoji and Edokpayi, 2013). Further studies have shown that macroinvertebrates are more abundant in floating macrophytes than sediment and littoral or bankroot biotopes (Ogbeibu and Aganmwonyi, 2005), yet little is known on the possible role of livestock grazing around riparian zones or rivers on the macroinvertebrate abundance and community structure. The objective of this study is to investigate the impact of livestock grazing on the abundance of macroinvertebrates in both E. crassipes and littoral sediment biotope.

\section{MATERIALS AND METHOD}

This study was carried out in a stretch of Ovia River along Benin Ore express road. The river takes its source from Akptata hills in Ekiti State, Nigeria and flows through southern part of Edo State, between latitude $5^{\circ} 20$ and $6^{\circ} 35 \mathrm{~N}$ and longitude $5^{\circ} 05$ and $5^{\circ}$ $40 \mathrm{E}$ (Figure 1). This river flows through a dense forest in which runoff and organic matter from surrounding vegetation adds to allochthonous input.

Three sampling stations were selected for this study based on their importance as grazing sites for Fulani herdsmen. In each station samples were collected 
from floating Eichornia crassipes and littoral sediment. Station I was located upstream, about $400 \mathrm{~m}$ from the brigde. Fulani herdsmen often grazed their cattle around this station. The marginal vegetation comprised of mid-sized shrubs, grasses and floating macrophytes, particularly E. crassipes. The substratum was mostly a mixture of sand and clay. Station II was downstream of station I, located at about $80 \mathrm{~m}$ after the bridge. Heavy siltation occurs here due to the grazing activities that have left the surface nearly bare of grasses or any other form of vegetation. Station III was located at about $300 \mathrm{~m}$, downstream of station II. The dominant vegetation around this station was trees, a few shrubs and grasses. Minimal human activities were noticed in this station.

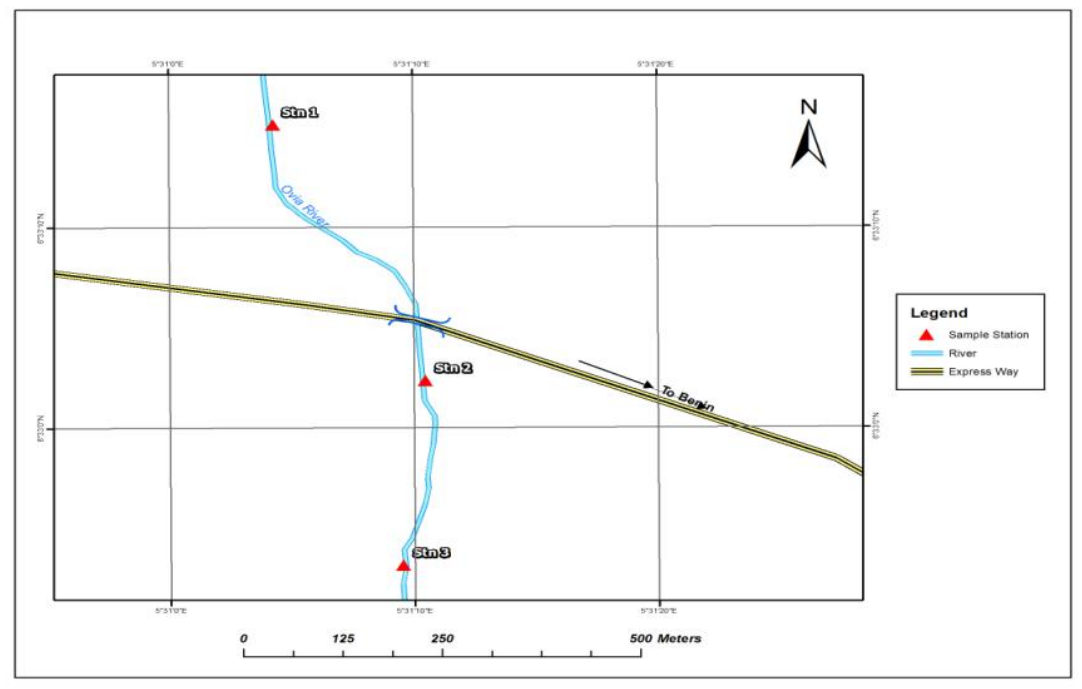

Fig 1: Map of study Area

Samples were collected fortnightly between 8.00 am and 12.00 noon, for six months (January to June, 2004). Air, water temperature and transparency were measured in situ using mercury in glass thermometer and secchi disc respectively. Water samples were collected and analysed for conductivity, turbidity, $\mathrm{pH}$, alkalinity, nitrates, sulphates and phosphates. DO and BOD of water samples were analysed.

Macroinvertebrates were collected from floating $E$. crassipes and littoral sediment. Five stands of $E$. crassipes was sampled in each station, and placed in a bucket containing little quantity of water and $40 \%$ formaldehyde for 2 minutes, and then vigorously dusted inside the bucket. A $1.0 \mathrm{~mm}$ sieve was used to sieve the content of the bucket to exclude large particles and debris from the sample, after which the $0.5 \mathrm{~mm}$ sieve was used. The residues retained in the $0.5 \mathrm{~mm}$ sieve were washed into wide-mouthed specimen containers and fixed in $10 \%$ formaldehyde. Kick sampling technique described by Victor and Ogbeibu, 1986 was employed in the collection of benthic macroinvertebrates from the bank root sediment. The organisms was then washed and stored in pre-labelled wide-mouthed bottles and fixed with $10 \%$ formaldehyde. The macroinvertebrates collected from each station were then sorted into different taxonomic groups using an American Optical Dissecting microscope with a magnification of $25-$ 40x. Each taxonomic group was placed in a specimen bottle containing $4 \%$ formalin and properly labelled.
The macroinvertebrates were later identified to genus or species level where possible with a compound microscope using identification guides (Edmondson, 1959; Clegg, 1969; Bouchard, 2004). Each identified taxon was counted and the number of individuals recorded on station by station basis.

\section{RESULTS AND DISCUSSION}

Table 1 summarizes the physical and chemical conditions of the study stations. There was no significant difference $(\mathrm{P}>0.05)$ in all the parameters analysed, except water temperature $(\mathrm{P}=0.02)$ and nitrate $(\mathrm{P}<0.001)$. A Tukey post-hoc test revealed that water temperature was statistically significantly lower in station II $(24.20 \pm 0.28)$ and station III $(24.20 \pm 0.28)$ compared to station I (25.45 \pm 0.43$)$. Likewise, Tukey post-hoc test revealed that nitrate concentration in station I $(2.50 \pm 0.21)$ and II $(2.01 \pm 0.13)$ were statistically significantly higher than station III $(1.23 \pm 0.10)$. Water temperature difference was due to the time lag in sampling station II and III and then crossing over to station I. The nitrate concentration in station I and II could be attributed to the increase in organic waste from cattle dung in station I and runoff from surrounding farmstead and settlements in station II.

In this study, 33 taxa of macroinvertebrates with 831 individuals were encountered (table 2). The abundance of macro invertebrates was highest in the E. crassipes biotope in all the stations compared to 
the littoral sediment. The macro invertebrates encountered were dominated by Insecta which accounted for $89.41 \%$ of the total number of individuals recorded in the study. Class Insecta was represented seven orders. Ephemeroptera was represented by Families Baetidae, Leptophlebiidae, Siphlonuridae, Caenidae and Trichorythidae. Tricoptera, Coleoptera and Diptera were represented by two families each; Leptoceridae and
Limnephillidae, Haliplidae and Dytiscidae, Chironomidae and Culicidae respectively. Hemiptera, Odonata and Anisoptera all recorded one family each namely, Notonectidae, Coenagrionidae and Libellulidae. Oligochaeta accounted for $8.90 \%$ of the total number of species encountered, represented by family Naididae. Class Crustacea constituted $1.20 \%$, while Class Gastropoda and Arachnida accounted for $0.24 \%$ of the total number of species

Table 1: Summary of the physico-chemical parameters of the study stations in Ovia River

\begin{tabular}{|c|c|c|c|c|c|c|c|c|c|c|c|}
\hline \multirow[b]{2}{*}{ Parameters } & \multicolumn{3}{|c|}{ Station I } & \multicolumn{3}{|c|}{ Station II } & \multicolumn{5}{|c|}{ Station III } \\
\hline & Min & Max & Mean \pm SE & Min & Max & Mean \pm SE & Min & Max & Mean \pm SE & P-Value & $\bar{n}$ \\
\hline Air Temperature ${ }^{0} \mathrm{C}$ & 25.5 & 30 & $28.25 \pm 0.45$ & 25 & 28.5 & $27.05 \pm 0.33$ & 25 & 28.5 & $27.15 \pm 0.33$ & 0.06 & 10 \\
\hline Water Temperature ${ }^{0} \mathrm{C}$ & 23 & 27 & $25.45 \pm 0.43$ & 23 & 25.5 & $24.20 \pm 0.28$ & 23 & 25.5 & $24.20 \pm 0.28$ & 0.02 & 10 \\
\hline Transparency $(\mathbf{c m})$ & 26 & 53 & $34.90 \pm 2.81$ & 26 & 58 & $35.50 \pm 3.02$ & 26 & 47 & $32.40 \pm 2.30$ & 0.70 & 10 \\
\hline Dissolved Oxygen $\left(\mathrm{mgL}^{-1}\right)$ & 5.8 & 9.4 & $7.79 \pm 0.39$ & 6.2 & 13.3 & $8.73 \pm 0.67$ & 7.2 & 11.7 & $8.75 \pm 0.38$ & 0.34 & 10 \\
\hline BOD $\left(\mathrm{mgL}^{-1}\right)$ & 1.2 & 4 & $2.43 \pm 0.31$ & 0.9 & 4.9 & $2.44 \pm 0.47$ & 1.6 & 6.4 & $2.92 \pm 0.43$ & 0.64 & \\
\hline pH & 5.5 & 7.2 & $6.52 \pm 0.17$ & 6 & 7.3 & $6.62 \pm 0.12$ & 6 & 7 & $6.49 \pm 0.10$ & 0.78 & 10 \\
\hline Turbidity (NTU) & 0.04 & 0.15 & $0.079 \pm 0.01$ & 0.04 & 0.16 & $0.082 \pm 0.01$ & 0.03 & 0.11 & $0.062 \pm 0.01$ & 0.37 & 10 \\
\hline Conductivity $(\mu \mathrm{S} / \mathrm{cm})$ & 0.016 & 0.087 & $0.039 \pm 0.01$ & 0.018 & 0.085 & $0.034 \pm 0.01$ & 0.01 & 0.034 & $0.020 \pm 0.002$ & 0.05 & 10 \\
\hline Sulphate $\left(\mathrm{mgL}^{-1}\right)$ & 37 & 90.2 & $51.46 \pm 6.56$ & 32.8 & 89.8 & $49.25 \pm 6.63$ & 33 & 85.5 & $47.56 \pm 56$ & 0.92 & 10 \\
\hline Nitrate $\left(\mathrm{mgL}^{-1}\right)$ & 1.79 & 3.95 & $2.50 \pm 0.21$ & 1.54 & 2.95 & $2.01 \pm 0.13$ & 0.86 & 1.61 & $1.23 \pm 0.10$ & 0.00 & 10 \\
\hline Phosphate (mgL $\left.{ }^{-1}\right)$ & 0.02 & 1.1 & $0.45 \pm 0.16$ & 0.02 & 1.05 & $0.35 \pm 0.15$ & 0.01 & 0.07 & $0.04 \pm 0.01$ & 0.07 & 10 \\
\hline
\end{tabular}

Table 2: Composition and distribution of macroinvertebrate fauna in Ovia River

\begin{tabular}{|c|c|c|c|c|c|c|}
\hline & Station I & & Station II & & Station III & \\
\hline Taxa & $\begin{array}{l}\text { E. } \\
\text { crassipess }\end{array}$ & $\begin{array}{l}\text { Littoral } \\
\text { Sediment }\end{array}$ & $\begin{array}{l}\text { E. } \\
\text { crassipess }\end{array}$ & $\begin{array}{l}\text { Littoral } \\
\text { Sediment }\end{array}$ & $\begin{array}{l}\text { E. } \\
\text { crassipess }\end{array}$ & $\begin{array}{l}\text { Littoral } \\
\text { Sediment }\end{array}$ \\
\hline \multicolumn{7}{|l|}{ Oligochaeta } \\
\hline Dero sp & 6 & 2 & 3 & 3 & 10 & 2 \\
\hline $\begin{array}{l}\text { Nais simplex } \\
\text { Stylaria fossularis } \\
\text { Insecta } \\
\text { Ephemeroptera } \\
\text { Baetidae }\end{array}$ & $\begin{array}{l}8 \\
5\end{array}$ & $\begin{array}{l}2 \\
1\end{array}$ & $\begin{array}{l}2 \\
1\end{array}$ & $\begin{array}{l}2 \\
0\end{array}$ & $\begin{array}{l}11 \\
9\end{array}$ & $\begin{array}{l}3 \\
4\end{array}$ \\
\hline Centroptilum sp & 10 & 5 & 3 & 1 & 18 & 2 \\
\hline Baetis tricaudatus & 9 & 2 & 2 & 0 & 15 & 0 \\
\hline Cloeon bellum & 8 & 1 & 2 & 1 & 11 & 0 \\
\hline $\begin{array}{l}\text { Pseudocloen sp } \\
\text { Leptophlebiidae }\end{array}$ & 3 & 0 & 0 & 0 & 2 & 0 \\
\hline $\begin{array}{l}\text { Adenophlebiodes sp } \\
\text { Habrophlebia sp } \\
\text { Siphlonuridae }\end{array}$ & $\begin{array}{l}7 \\
5\end{array}$ & $\begin{array}{l}1 \\
0\end{array}$ & $\begin{array}{l}2 \\
1\end{array}$ & $\begin{array}{l}0 \\
0\end{array}$ & $\begin{array}{l}11 \\
6\end{array}$ & $\begin{array}{l}2 \\
1\end{array}$ \\
\hline Siphlonurus sp & 9 & 1 & 2 & 0 & 10 & 3 \\
\hline \multicolumn{7}{|l|}{ Caenidae } \\
\hline Caenis sp & 7 & 5 & 1 & 0 & 20 & 3 \\
\hline Caenodes sp & 10 & 3 & 3 & 2 & 11 & 2 \\
\hline Trichorythidae & & & & & & \\
\hline
\end{tabular}




\begin{tabular}{|c|c|c|c|c|c|c|}
\hline Diceromyzon sp & 4 & 0 & 0 & 0 & 7 & 0 \\
\hline \multicolumn{7}{|l|}{ Tricoptera } \\
\hline \multicolumn{7}{|l|}{ Leptoceridae } \\
\hline Leptocella sp & 5 & 0 & 2 & 0 & 9 & 2 \\
\hline \multicolumn{7}{|l|}{ Limnephillidae } \\
\hline Limnephilus sp & 0 & 0 & 1 & 0 & 6 & 0 \\
\hline \multicolumn{7}{|l|}{$\begin{array}{l}\text { Hemiptera } \\
\text { Notonectidae }\end{array}$} \\
\hline Notonecta sp & 3 & 0 & 1 & 0 & 7 & 1 \\
\hline \multicolumn{7}{|l|}{ Coleoptera } \\
\hline \multicolumn{7}{|l|}{ Haliplidae } \\
\hline Haliplus sp & 2 & 0 & 0 & 0 & 4 & 1 \\
\hline \multicolumn{7}{|l|}{ Dytiscidae } \\
\hline Dytiscus marginalis & 7 & 0 & 3 & 0 & 11 & 2 \\
\hline Deronectes sp & 4 & 0 & 1 & 0 & 5 & 0 \\
\hline \multicolumn{7}{|l|}{ Diptera } \\
\hline \multicolumn{7}{|l|}{ Chironomidae } \\
\hline Pentaneura sp & 27 & 11 & 8 & 3 & 41 & 11 \\
\hline Polypedilum sp & 21 & 9 & 11 & 3 & 29 & 3 \\
\hline Tanytarsus sp & 13 & 0 & 0 & 0 & 12 & 2 \\
\hline Probezzia sp & 0 & 0 & 0 & 0 & 12 & 2 \\
\hline Corynomeura sp & 17 & 7 & 13 & 2 & 17 & 4 \\
\hline \multicolumn{7}{|l|}{ Culicidae } \\
\hline Culex sp & 4 & 0 & 0 & 0 & 11 & 0 \\
\hline \multicolumn{7}{|l|}{ Odonata } \\
\hline \multicolumn{7}{|l|}{ Zygoptera } \\
\hline \multicolumn{7}{|l|}{ Coenagrionidae } \\
\hline Agrion sp & 12 & 2 & 0 & 1 & 18 & 2 \\
\hline Enallagma sp & 10 & 1 & 2 & 0 & 16 & 0 \\
\hline Ischnura sp & 4 & 0 & 1 & 0 & 8 & 0 \\
\hline \multicolumn{7}{|l|}{ Anisoptera } \\
\hline \multicolumn{7}{|l|}{ Libellulidae } \\
\hline Libellula sp & 8 & 0 & 4 & 0 & 12 & 2 \\
\hline Cordulia sp & 6 & 0 & 1 & 0 & 4 & 0 \\
\hline \multicolumn{7}{|l|}{ Crustacea } \\
\hline \multicolumn{7}{|l|}{ Decapoda } \\
\hline $\begin{array}{l}\text { Palemonidae } \\
\text { Macrobranchium sp } \\
\text { Arachnida }\end{array}$ & 4 & 0 & 1 & 0 & 5 & 0 \\
\hline Argyroneta sp & 0 & 0 & 0 & 0 & 2 & 0 \\
\hline $\begin{array}{l}\text { Mollusca } \\
\text { Gastropoda } \\
\text { Ampullaridae }\end{array}$ & & & & & & \\
\hline Pila sp & 0 & 0 & 0 & 0 & 2 & 0 \\
\hline TOTAL & 238 & 53 & 71 & 18 & 372 & 54 \\
\hline
\end{tabular}


Figure 2 shows the abundance of macro invertebrate fauna across the three study stations. Species abundance was particularly low in station II, which was the grazing area occupied by the Fulani Herds Men before they relocated station I. The abundance of macro invertebrate fauna in Eichhornia crassipes biotope was significantly different from the abundance recorded in the littoral sediment biotope. E.crassipes affects assemblages, abundance and enhances biodiversity of macro invertebrates due to favourable habitat conditions presented by the roots of water hyacinth. This result agrees with the report of Masifwa et al. (2001), that water hyacinth appeared to enhance the abundance and diversity of aquatic macro invertebrates at the interface with open water, owing to the contribution of the plants to dissolved oxygen concentration of the river in the shallow edge of the river with the fringe of water hyacinth plants that have formed mats floating around the edge of the river.

The overall abundance of macro invertebrate fauna was highly significantly different across the stations $(\mathrm{P}<0.01)$. Further test using Dunnett's T3 test revealed that the abundance of macro invertebrate fauna was significantly higher in stations I and III. The comparison of means of station I where Fulani Herdsmen relocated their cattle for grazing and station III revealed that the abundance of macro invertebrate fauna was statistically significant different in both stations.

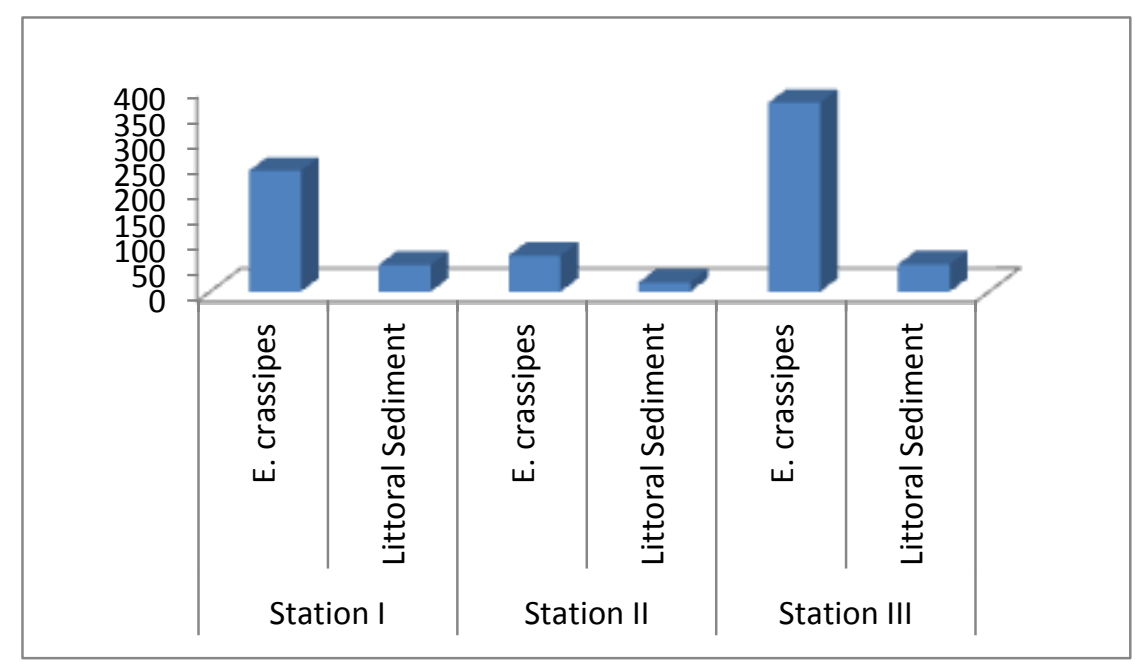

Fig 2: Abundance of macroinvertebrate fauna in the study stations.

The significant loss of riparian vegetation which is a direct result of grazing and trampling effect of cattle led to the continuous sedimentation in station II. Consequently, the littoral zone of station II constantly received influx of sand and debris during rainfall events. The apparent low abundance of macroinvertebrate species in this station was attributed to this factor. This is corroborated by the low abundance of Ephemeroptera and Tricoptera species in the station. Hence, some species belonging to families Baetidae (Pseudocloen sp), Trichorythidae (Diceromyzon sp), Haliplidae (Haliplus sp), Culicidae (Culex sp), Chironomidae (Tanytarsus sp and Probezzia sp), Ampullaridae (Pila sp) and Argyronecta sp belonging to Order Arachnida) were not encountered in station II. Although posteriori Dunnett's T3 test showed that the abundance of macroinvertebrate fauna was significantly higher in stations I and III, further studies is recommended to monitor the trend in macro invertebrate abundance in both stations. This is due to the relocation of the cattle herders to the land adjacent to station I in the last two months of this study, which could be the factor responsible for the difference in abundance in stations I and III. The low species abundance in station II is an indication that cattle grazing had significant impact on macroinvertebrate fauna abundance. Consequently governments at all levels should make effort to create lands for Fulani Herdsmen to graze their cattle.

\section{REFERENCES}

Adeogun, A O; Fafioye, O O. (2011). Impact of effluents on water quality and benthic macroinvertebrate fauna of Awba Stream and Reservoir. Journal of Applied Science and Environmental Management 15 (1): 105-113.

Ajuzie, C C. (2012). Macroinvertebrate communities in two tropical reservoirs (Lamingo and Liberty reservoirs) in Jos, Nigeria. Nature and Science 10 (2): 8-18.

Allan, J D. (2004). Landscapes and riverscapes: the influence of land use on stream ecosystems. Annual review of ecology evolution and systematics $35: 257-284$. 
Bouchard, R W. (Jr) (2004). Guide to Aquatic Invertebrates of the Upper Midwest. University of Minnesota, 207pp.

Clegg, J. (1969). The Freshwater Life of the British Isles. Frederick Warne and Co Ltd. 352pp.

Collier, K J; Quinn, J M. (2003). Land-use influences macroinvertebrate community response following a pulse disturbance. Freshwater Biology 48: 1462-1481.

Covich, A P; Palmer, M A; Crowl, T A. (1999). The role of benthic invertebrates species in freshwater ecosystem. BioScience 49(2): 119127.

Edmondson, W T. (1959). Freshwater Biology $2^{\text {nd }}$ Edition. John Wiley and Sons Inc. 1248pp.

Hussain, Q A; Pandit, A K. (2012). Macroinvertebrates in streams: A review of some ecological factors. International Journal of Fisheries and Aquaculture 4(7): 114-123. Available online at http://www.academicjournals.org/IJFA.

Ikomi, R B; Arimoro, F O; Odihirin, O K. (2005). Composition, distribution and abundance of macro invertebrates of the upper reaches of river Ethiope, Delta State, Nigeria. Zoologist 3: 68-81.

Imoobe, T O T; Ohiozebau, E. (2010). Pollution status of a tropical forest river using aquatic insects as indicators. African Journal of Ecology 48 (1): 232-238.

Jimoh, A A; Clarke, E O; Whenu, O O; Adeoye, H B. (2011). Food and feeding habits of the African river prawn ((Macrobrachium vollenhovenii, Herklots, 1857) in Epe Lagoon, Southwest Nigeria. Int. J. Fish. Aquacul. 3(1):10-15.

Kenney, M A; Sutton-Grier, A E; Smith, R F; Gresens, S E. (2009). Benthic macroinvertebrates as indicators of water quality: The intersection of science and policy. Terrestrial Arthropod Reviews 2: 99-128.

Lake, P S. (2000). Disturbance, patchiness, and diversity in streams. Journal of the North American Benthological Society 19: 573-592.

Malmqvist, B; Rundle, S; Bronmark, C; Erlandsson, A. (1991). Invertebrate colonization of a new, man-made stream in southern Sweden. Freshwater Biology 26: 307-324.
Masifwa, W F; Twongo, T; Denny, P. (2001). The impact of water hyacinth, Eichhornia crassipes (Mart) Solms on the abundance and diversity of aquatic macrophytes along the shores of northern Lake Victoria, Uganda. Hydrobiologia 452: 7988.

Milner, A M; Knudsen, E E; Soiseth, C; Robertson, A L; Schell, D; Phillips, I T; Magnusson, T. (2000). Colonization and development of stream communities across a 22-year gradient in Glacier Bay National Park, Alaska, U.S.A. Can. J. Fish. Aquat Sci 57: 2319-2335.

Moore, A A; Palmer, M A. (2005). Invertebrate biodiversity in agricultural and urban headwater streams: implications for conservation and management. Ecological Applications 15(4): 1169-1177.

Nkwoji, J A; Edokpayi, C A. (2013). Hydrochemistry and community structure of Benthic Macroinvertebrates of Lagos Lagoon, Nigeria. Research Journal of Pharmaceutical, Biological and Chemical Sciences 4 (2): 1119-1131.

Paul, M J; Meyer, J L. (2001). Streams in the urban landscape. Annual Review of Ecology and Systematics 32: 333-365.

Ravera, O. (2000). Ecological monitoring for water body management. Proceeding of Monitoring Tailor-Made III. International Workshop on Information for Sustainable Water Management, pp: 157-167.

Sahuquillo, M; Poquet, J M; Rueda, J; Miracle, J M. (2007). Macroinvertebrate communities in sediment and plants in coastal Mediterranean water bodies (Central Iberian Peninsula). Ann. Limnol.-Int. J. Lim. 43 (2): 117-130.

Thompson, R M; Townsend, C R. (2003). Impacts on stream food webs of native and exotic forest: An intercontinental comparison. Ecology 84: 145161.

Virbickas, T; Pliurate, V; Kesminas, V. (2011). Impact of agricultural land use on macroinvertebrate fauna in Lithuania. Pol. J. Environ. Stud 20 (5): 1327-1334.

Wallace, J B; Webster, J R. (1996). The role of macroinvertebrates in stream ecosystem function. Annual Review of Entomology 41: 115-139. 